\title{
Potential plasma biomarkers of bladder cancer identified by proteomic analysis: A pilot study
}

\author{
Anna Lemańska-Perek ${ }^{* 1, A-D, F}$, Jolanta Lis-Kuberka*1,A-D,F, Adam Lepczyński2,B,C,E,F, Alicja Dratwa-Chałupnik2,B,C,E,F, \\ Krzysztof Tupikowskiं ${ }^{3,4, E, F}$, Iwona Kątnik-Prastowska ${ }^{1, C, E, F}$, Małgorzata 0żg2 2,B,, E,F \\ ${ }^{1}$ Department of Chemistry and Immunochemistry, Wroclaw Medical University, Poland \\ 2 Department of Physiology, Cytobiology and Proteomics, West Pomeranian University of Technology, Szczecin, Poland \\ ${ }^{3}$ Department of Urology and Oncologic Urology, Wroclaw Medical University, Poland \\ ${ }^{4}$ Department of Oncologic Urology, Lower Silesian Oncology Center, Wrocław, Poland \\ A - research concept and design; B - collection and/or assembly of data; $\mathrm{C}$ - data analysis and interpretation; \\ $D$ - writing the article; $E$ - critical revision of the article; $F$ - final approval of the article
}

\section{Address for correspondence}

Anna Lemańska-Perek

Email:anna.lemanska-perek@umed.wroc.pl

Funding sources

None declared

Conflict of interest

None declared

* These authors contributed equally to this work.

Received on April 13, 2017

Reviewed on July 18, 2017

Accepted on October 27, 2017

Published online on July 2, 2018

Cite as

Lemańska-Perek A, Lis-Kuberka J, Lepczyński A, et al.

Potential plasma biomarkers of bladder cancer identified by proteomic analysis: A pilot study. Adv Clin Exp Med. 2019;28(3):339-346. doi:10.17219/acem/79296

DOI

10.17219/acem/79296

Copyright

Copyright by Author(s)

This is an article distributed under the terms of the

Creative Commons Attribution Non-Commercial License

(http://creativecommons.org/licenses/by-nc-nd/4.0/)

\section{Abstract}

Background. Bladder cancer diagnosis and surveillance includes cystoscopy and cytology. New methods for the detection of bladder cancer are needed, because cystoscopy is invasive and expensive, and because urine cytology is not sensitive enough.

Objectives. The aim of the study was to select potential plasma protein markers for bladder cancer which could be useful in developing a specific laboratory test to improve diagnosis and to establish treatment strategies in order to prevent the recurrence of the disease.

Material and methods. Plasma proteome maps were prepared based on 2-dimensional sodium dodecyl sulfate polyacrylamide gel electrophoresis (SDS-PAGE), combined with image gel analysis and matrix-assisted laser desorption/ionization time-of-flight (MALDI-TOF) mass spectrometry of plasma samples from patients with urothelial bladder cancer, and they were compared to normal samples.

Results. The analyses of bladder cancer plasma samples allowed us to distinguish 3 groups of proteins whose relative abundance differed from that in normal samples. The $1^{\text {st }}$ one comprised modified forms of plasma transferrin, fibrinogen gamma and complement C $3 b$, which were absent in normal plasma. The $2^{\text {nd }}$ group comprised haptoglobin, alpha-2-macroglobulin, vitamin D-binding protein, and pigment epithelium-derived factor, which occurred in the cancerous samples in large quantities. The $3^{\text {rd }}$ group consisted of 3 molecular forms of immunoglobulin $\mathrm{M}(\mathrm{lgM})$, the relative abundance of which was significantly lower in the cancerous plasma samples.

Conclusions. The data indicated potential plasma biomarkers associated with inflammation, immunity and coagulation processes accompanying bladder cancer. They could be used for the development of a laboratory test(s) useful in clinical practice.

Key words: bladder cancer, biomarkers, proteomics, blood plasma glycoproteins, 2-dimensional gel electrophoresis 


\section{Introduction}

Bladder cancer is often symptomless or may produce symptoms similar to a urinary tract infection. The tumors are routinely evaluated by cystoscopy, an invasive endoscopic procedure in order to aid diagnosis and post-treatment surveillance; intensive efforts have been undertaken to research and develop specific, sensitive and non-invasive tests based on a marker or group of markers. ${ }^{1}$ The aim is the early detection of primary or recurrent bladder cancer, which might help in establishing new treatment strategies, monitoring treatment and preventing recurrence. ${ }^{2,3}$

Biomarkers described to date are tumor-associated molecules that degrade the components of the extracellular matrix and the urothelium. The US Food and Drug Administration has approved only a few of them, i.e., bladder tumor antigen (BTA), nuclear matrix protein 22 (NMP22) and fibrinogen degradation products. ${ }^{4-6}$ Moreover, the following molecules that are still under investigation have been reported to be associated with urinary carcinogenesis: BLCA-4, cytokeratin, fibronectin degradation products, uroplakins and their glycovariants, psoriasin, zinc-alpha-2-glycoprotein, pro-matrix metalloproteinase-2 (proMMP-2), matrix metalloproteinase-7 (MMP-7), and endostatin. ${ }^{7-13}$ It has also been reported that the serum levels of CYFRA 21-1 and soluble E-cadherin are associated with advanced and high-grade urothelial bladder carcinoma. ${ }^{14,15}$ In the opinion of Goodison et al., most of these biomarkers may be more useful as prognostic factors aiding therapeutic decisions. So far, none of the recommended urinary cancer biomarkers have been found to be sufficiently sensitive and specific to detect the entire spectrum of bladder cancers and to be used in routine clinical practice. ${ }^{3}$

A new powerful and complex tool - proteomics, using 2-dimensional gel electrophoresis (2DE) to separate complete proteins in a sample, and immunoblotting or mass spectroscopy (MS) techniques, integrated with advanced computer software, make it possible to precisely identify, characterize and quantify the data. It is usually used to select potential marker proteins from complex protein mixtures for further analysis in larger groups. So far, a 2-dimensional gel-based proteomic approach coupled with MS and database searching has been used in order to explore the biomarkers of bladder cancer in urinary samples, tissue samples derived from biopsies from the transurethral resections of the bladder and patients' plasma samples. ${ }^{16-18}$ Despite the abovementioned pioneering studies which have shed some light on the molecular mechanisms of bladder transitional cell carcinoma, there is still a great need to identify novel proteins or a group of bladder cancer biomarkers.

The aim of our study was to analyze differentially expressed levels of proteins in the plasma samples of patients with urothelial bladder cancer and acute cystitis by 2 -dimensional sodium dodecyl sulfate polyacrylamide gel electrophoresis (SDS-PAGE), combined with image gel analysis and matrix-assisted laser desorption/ionization time-of-flight (MALDI-TOF) MS. Furthermore, the goal was to select a group of potential protein markers of bladder cancer which might be used in the development of a laboratory test(s) useful in clinical practice.

\section{Material and methods}

\section{Blood plasma sample collection}

Blood samples were obtained from 6 patients (54-91 years old) from the Department of Urology and Oncologic Urology of Wroclaw Medical University, Poland, who were being treated for bladder cancer. They were included in the study after providing written informed consent. The study was approved by the local Bioethical Committee (KB-406/2014).

The tumor was staged according to the TNM Classification of Malignant Tumors (TNM) and graded according to World Health Organization/International Society of Urologic Pathology (WHO/ISUP) 2004 criteria. ${ }^{19,20}$ The bladder cancer patients' samples were divided into 2 groups according to the disease stage. The $1^{\text {st }}$ group $(C)$ comprised samples derived from 4 patients ( 2 women and 2 men, aged $70.8 \pm 17$ years) with bladder tumors. The $2^{\text {nd }}$ group (S), suspected of having cancer, consisted of 2 samples of patients ( 2 men, aged $62.5 \pm 0.7$ years) who had undergone the transurethral resection of urothelial bladder cancer about 2 years earlier and were recurrencefree, but suffered from acute cystitis, lasting approx. 2 weeks.

The normal group $(\mathrm{H})$ consisted of healthy volunteers aged $48.7 \pm 4$ years ( 3 women).

\section{Blood plasma sample preparation}

The blood was drawn into plastic test tubes containing sodium citrate as an anticoagulant (1 part of 3.8\% (w/v) citrate to 9 parts of the sample) and the plasma was separated from the blood cells by centrifugation at 2,000 $\times \mathrm{g}$ for $15 \mathrm{~min}$. The samples were stored at $-76^{\circ} \mathrm{C}$ until used.

Blood plasma samples were depleted of the 2 most abundant proteins, using a ProteoExtract Albumin/IgG Removal Kit, Maxi (Calbiochem Merck, Geneva, Switzerland) to enrich the content of medium- and low-abundant protein in this medium. Depleted samples were subsequently precipitated with 4 volumes of cold acetone $\left(-20^{\circ} \mathrm{C}\right)$ for $2 \mathrm{~h}$ and then centrifuged $\left(20,800 \times \mathrm{g}, 4^{\circ} \mathrm{C}, 30 \mathrm{~min}\right)$ to obtain protein pellets. The protein pellets were dissolved in lysis buffer, containing $7 \mathrm{M}$ of urea, $2 \mathrm{M}$ of thiourea, $4 \% \mathrm{w} / \mathrm{v}$ of 3-[(3-cholamidopropyl)dimethylammonio]-1-propanesulfonate (CHAPS), 1\% w/v of DL-dithiothreitol (DTT), $0.2 \% \mathrm{w} / \mathrm{v}$ of 3-10 carrier ampholytes, and $2 \mathrm{mM}$ of tributylphosphine (TBP). The protein concentration in the samples was determined by a modified Bradford assay (Bio-Rad6 Protein Assay; Bio-Rad, Hercules, USA), according to the manufacturer's instructions. 


\section{Two-dimensional electrophoresis}

Isoelectric focusing (IEF) was performed after loading blood plasma proteins $(800 \mu \mathrm{g})$ on 5-8 $24 \mathrm{~cm}$ nonlinear (NL) ReadyStrip IPG Strips (Bio-Rad). The proteins were separated for a total of 90,000 Vh, using a Protean IEF Cell (Bio-Rad). After IEF, the immobilized pH gradient (IPG) strips gained equilibrium at room temperature in a buffer solution containing $6 \mathrm{M}$ of urea, $0.5 \mathrm{M}$ of Tris/hydrochloric acid (pH 6.8), 2\% w/v of sodium dodecyl sulfate (SDS), $30 \%$ $\mathrm{w} / \mathrm{v}$ of glycerol, and additional $1 \% \mathrm{w} / \mathrm{v}$ of DTT to reduce the separated polypeptides $(15 \mathrm{~min})$ or $2.5 \% \mathrm{w} / \mathrm{v}$ of iodoacetamide to alkylate the proteins (20 min). Subsequently, the proteins were separated according to molecular range $(\mathrm{SDS}-\mathrm{PAGE})$ in $12 \%$ polyacrylamide gels $(20 \times 25 \mathrm{~cm})$ at $40 \mathrm{~V}$ for $2.5 \mathrm{~h}$, and then at $100 \mathrm{~V}$ for $16 \mathrm{~h}$ at $10^{\circ} \mathrm{C}$, using a Protean Plus Dodeca Cell electrophoretic chamber (Bio-Rad). The proteins were visualized using Coomassie brilliant blue G-250 according to the protocol described by Lepczyński et al. ${ }^{21}$

\section{Image analysis}

The acquisition of gel images was performed using a GS-800 Calibrated Densitometer (Bio-Rad). To align and quantify the protein spots, the PDQuest Advanced 2D-Gel Analysis Software v. 8.0.1 (Bio-Rad) was used. PDQuest enables the user to calculate the value of relative protein expression based on several measurements of the optical density of spot coloration intensity, and to quantify the protein spot area in order to represent it as a dimensionless quantity. The normalization of the experimental data was performed using a local regression model (LOESS). The significance of the differences in protein spot abundances was confirmed using Student's t-test within the PDQuest software. The significance of the differences was set at $\mathrm{p} \leq 0.05$. To evaluate the intragroup variability, the coefficients of variation $(\mathrm{CV})$ for each group were calculated based on the information about the location and relative expression for each protein spot within the groups. The experimental molecular masses of the identified protein spots were computed using Precision Plus Protein Kaleidoscope Standard for SDS-PAGE (Bio-Rad) as the reference.

\section{Matrix-assisted laser desorption/ionization time-of-flight mass spectrometry protein identification}

Following 2DE, the protein spots that showed significantly differentiated expression were identified by MALDI-TOF MS as previously described by Ożgo et al. ${ }^{22}$ Briefly, the protein spots were excised from the gels, decolorized (washed in a buffer solution containing $25 \mathrm{mM}$ of ammonium bicarbonate $\left[\mathrm{NH}_{4} \mathrm{HCO}_{3}\right]$ in $5 \% \mathrm{v} / \mathrm{v}$ of acetonitrile $\left.[\mathrm{ACN}]\right)$, then washed twice in a solution of $25 \mathrm{mM}$ of $\mathrm{NH}_{4} \mathrm{HCO}_{3}$ in $50 \% \mathrm{v} / \mathrm{v}$ of $\mathrm{ACN}$, dehydrated (100\% ACN), vacuum-dried, and incubated overnight with trypsin $(8 \mu \mathrm{L} / \mathrm{spot}$ of $12.5 \mu \mathrm{g}$ of trypsin/mL in $40 \mathrm{mM}$ of $\mathrm{NH}_{4} \mathrm{HCO}_{3}$ ) (Promega, Madison, USA) at $37^{\circ} \mathrm{C}$. After extraction with $100 \%$ $\mathrm{ACN}$, combined with an equal volume of matrix solution ( $2.5 \mathrm{mg} / \mathrm{mL}$ of $\alpha$-cyano-4-hydroxycinnamic acid [CHCA], $0.1 \% \mathrm{v} / \mathrm{v}$ of trifluoroacetic acid [TFA], $50 \% \mathrm{v} / \mathrm{v}$ of ACN), the obtained peptides were loaded onto a MALDI-MSP AnchorChip 600/96 plate (Bruker Daltonics, Bremen, Germany). Peptide Mass Standard II with a mass range of 700-3200 Da (Bruker Daltonics) was used to calibrate the mass scale.

The protein identification was done in the positive-ion reflector mode of a Microflex MALDI-TOF MS (Bruker Daltonics). The peptide mass fingerprinting (PMF) data were compared with the SwissProt/NCBI databases. The parameters used for the database search were: monoisotopic mass, 150 ppm mass accuracy, trypsin as an enzyme with 1 missed cleavage allowed, carbamidomethylation of cysteine as a fixed modification, and methionine oxidation as a variable modification. The results were further validated by the Mascot score and sequence coverage.

\section{Heat map generation}

PermutMatrix software v. 1.9.3 (The free access to the software is available on-line http://www.atgc-montpellier. $\mathrm{fr} /$ permutmatrix/) was used to create a heat map based on the data of the expression of the proteins in the healthy individuals, and in the cancer-suspected and cancerous patients. ${ }^{23}$ The data on protein expression level for each spot was normalized within rows, i.e., the mean expression level for each sample gel was calculated for each statistically differentially altered protein spot and the expression level of this protein for each gel was divided by the arithmetic mean. After division, it was subjected to base 2 logarithmic transformation. Thus, a negative value of the logarithm indicated a decrease in the expression, whereas a positive value showed an increase. In addition, the mean values were calculated based on the resulting values, but when the spot was absent on the gel ( 0 abundance), the 0 value was substituted by 1 .

\section{Results}

\section{Analysis of plasma proteome differences}

The analysis revealed from 361 to 387 protein spots per analyzed $2 \mathrm{D}$ gel, representing the protein profiles of the human plasma. Of them, 327 spots matched to each analyzed gel were subjected to statistical analysis between the cancer groups $\mathrm{C}$ and $\mathrm{S}$, and group $\mathrm{H}$. The $\mathrm{CV}$ was estimated to be $51.5 \%, 46.6 \%$ and $53.3 \%$ for groups $\mathrm{H}, \mathrm{C}$ and $\mathrm{S}$, respectively.

The significant quantitative differences in protein profiles revealed 15 differentially expressed protein spots (Fig. 1) in the plasma samples of patients with urothelial 
Table 1. Characterization of the plasma protein spots revealed by proteomic analyses of the bladder cancer plasma samples

\begin{tabular}{|c|c|c|c|c|c|c|c|c|c|c|}
\hline \multirow{2}{*}{$\begin{array}{l}\text { Spot } \\
\text { No. }\end{array}$} & \multirow{2}{*}{$\begin{array}{l}\text { Database protein name/ } \\
\text { identified blood plasma } \\
\text { protein }\end{array}$} & \multirow{2}{*}{$\begin{array}{l}\text { Accession } \\
\text { No. }\end{array}$} & \multirow{2}{*}{$\begin{array}{l}\text { Calculated } \\
\mathrm{Mr}[\mathrm{kDa}]\end{array}$} & \multirow{2}{*}{$\begin{array}{l}\text { Theoretical } \\
\mathrm{pl} / \mathrm{Mr}[\mathrm{kDa}]\end{array}$} & \multicolumn{3}{|c|}{$\begin{array}{l}\text { Mean relative abundance in the } \\
\text { groups }\end{array}$} & \multicolumn{3}{|c|}{ MALDI-TOF MS } \\
\hline & & & & & $\mathrm{H}$ & C & S & $\begin{array}{l}\text { Mascot } \\
\text { score }\end{array}$ & $\begin{array}{l}\text { Sequence } \\
\text { coverage } \\
(\%)\end{array}$ & $\begin{array}{l}\text { Mass } \\
\text { values } \\
\text { matched }\end{array}$ \\
\hline 1 & $\begin{array}{l}\text { haptoglobin/haptoglobin } \\
\beta \text { chain }\end{array}$ & Q9UC67 & 43.1 & $6.13 / 45.86$ & $29,968.2$ & $78,764.0$ & $93,212.1$ & 81 & 18 & 10 \\
\hline 2 & $\begin{array}{l}\text { haptoglobin/haptoglobin } \\
\beta \text { chain }\end{array}$ & Q9UC67 & 42.9 & $6.13 / 45.86$ & $2,616.9$ & $12,149.3$ & $14,759.0$ & 115 & 29 & 13 \\
\hline 3 & vitamin D-binding protein & P02774 & 59.2 & $5.40 / 54.53$ & $5,771.8$ & $47,832.1$ & $47,612.2$ & 228 & 59 & 25 \\
\hline 4 & alpha-2-macroglobulin & $1009174 \mathrm{~A}$ & 201.6 & $5.95 / 162.07$ & 234.8 & 731.1 & 940.5 & 90 & 13 & 13 \\
\hline 5 & fibrinogen gamma & 0602239A & 54.8 & $5.54 / 46.82$ & $4,206.8$ & $8,799.9$ & $6,449.0$ & 206 & 59 & 22 \\
\hline 6 & fibrinogen gamma & 0602239A & 54.1 & $5.54 / 46.82$ & $137,003.0$ & $246,912.8$ & $279,217.8$ & 146 & 51 & 14 \\
\hline 7 & fibrinogen gamma & 0602239A & 51.7 & $5.54 / 46.82$ & N/D & $2,274.0$ & $1,510.3$ & 133 & 53 & 15 \\
\hline 8 & serotransferrin & P02787 & 54.9 & $6.81 / 79.29$ & N/D & $1,626.1$ & $1,617.6$ & 107 & 22 & 17 \\
\hline 9 & $\begin{array}{l}\text { human complement } \\
\text { component } C 3 b \text {, chain B }\end{array}$ & 2107_B & 125.4 & $5.16 / 104.91$ & N/D & 645.7 & 980.2 & 71 & 18 & 15 \\
\hline 10 & $\begin{array}{l}\text { human complement } \\
\text { component } C 3 \mathrm{~b} \text {, chain B }\end{array}$ & 2107_B & 80.0 & $5.16 / 104.91$ & $3,139.7$ & $7,066.4$ & $5,018.1$ & 70 & 23 & 19 \\
\hline 11 & $\begin{array}{l}\text { pigment epithelium- } \\
\text { derived factor }\end{array}$ & AAA84914 & 51.0 & $6.56 / 40.22$ & $1,270.5$ & $2,831.3$ & $2,127.8$ & 78 & 34 & 11 \\
\hline 12 & $\begin{array}{l}\text { insulin-like growth factor } \\
\text { binding protein, acid } \\
\text { labile subunit }\end{array}$ & AAH25681 & 89.3 & $6.33 / 66.77$ & $1,367.2$ & 870.4 & $1,065.8$ & 111 & 27 & 13 \\
\hline 13 & $\begin{array}{l}\text { Ig mu chain C region/lgM } \\
\text { heavy chain }\end{array}$ & P01871 & 83.7 & $6.35 / 49.96$ & $15,616.3$ & $3,876.4$ & $1,819.6$ & 113 & 36 & 14 \\
\hline 14 & $\begin{array}{l}\text { Ig mu chain C region/lgM } \\
\text { heavy chain }\end{array}$ & P01871 & 83.0 & $6.35 / 49.96$ & $35,847.6$ & $7,263.2$ & $4,501.8$ & 129 & 36 & 14 \\
\hline 15 & $\begin{array}{l}\text { Ig mu chain C region/lgM } \\
\text { heavy chain }\end{array}$ & P01871 & 82.2 & $6.35 / 49.96$ & $51,699.2$ & $16,930.2$ & $15,115.7$ & 86 & 42 & 16 \\
\hline
\end{tabular}

Table 1 lists the differentially expressed plasma proteins abundantly occurring in the plasma samples of patients with bladder cancer and of healthy controls. The proteins were revealed (see labeled spots in Fig. 1) and identified by matrix-assisted laser desorption/ionization time-of-flight mass spectrometry (MALDI-TOF/TOF MS), following 2-dimensional electrophoresis (2DE) analysis. Protein names and accession numbers are given as found in the SwissProt/NCBI databases. C - patients with bladder tumors; $\mathrm{H}$ - healthy controls; IgM - immunoglobulin M; Mr - molecular mass; N/D - not detected in the normal plasma samples; pl - isoelectric point; $\mathbf{S}$ - patients suspected of having cancer.

bladder cancer and acute cystitis spots. The matched protein names identified by SwissProt/NCBI databases are given in Table 1. Fifteen selected spots were identified as 9 proteins (Table 1). They include the following proteins: 2 molecular forms of haptoglobin $\beta$ chain (spot 1: $43.1 \mathrm{kDa}$ and spot 2: $42.9 \mathrm{kDa}$ ), vitamin D-binding protein (spot 3: $59.2 \mathrm{kDa}$ ), alpha-2-macroglobulin (spot 4: $201.6 \mathrm{kDa}$ ), 3 forms of fibrinogen gamma (spots $5-7: 54.8 \mathrm{kDa}, 54.1 \mathrm{kDa}$ and $51.7 \mathrm{kDa}$, respectively), serotransferrin $(\operatorname{spot} 8: 54.9 \mathrm{kDa})$, 2 forms of human complement component C3b (spot 9: 125.4 kDa and spot 10: $80.0 \mathrm{kDa}$ ), pigment epitheliumderived factor (spot 11: $51.0 \mathrm{kDa}$ ), insulin-like growth factor binding protein (spot 12: $89.3 \mathrm{kDa}$ ), and 3 forms of immunoglobulin M (IgM) heavy chain (spots 13-15: 83.7 kDa, 83.0 kDa and 82.2 kDa, respectively).

Figure 2 presents a heat map which shows a comparative visualization of the individual levels of the differentially expressed protein spots in the control samples (H1-H3), the cancer-suspected samples (S1 and S2) and the bladder cancer patients' plasma samples $(\mathrm{C} 1-\mathrm{C} 4)$. The observed trends of the up- and downregulation of protein abundances in the cancerous and cancer-suspected samples analyzed in respect to those in the samples of healthy individuals are shown in Tables 1 and 2 .

The protein spots identified as transferrin $(54.9 \mathrm{kDa})$, fibrinogen gamma $(51.7 \mathrm{kDa})$ and complement $\mathrm{C} 3 \mathrm{~b}$ (125.4 kDa) occurred abundantly in both groups $\mathrm{C}$ and $\mathrm{S}$, but were absent in the normal plasma samples. The remaining identified proteins, apart from a low relative abundance of IgM, showed a high abundance in groups $C$ and $S$ compared with group $\mathrm{H}$.

The ratio values, which compare the relative abundance of the respective proteins between groups $\mathrm{C}$ and $\mathrm{H}, \mathrm{S}$ and $\mathrm{H}$, and $\mathrm{C}$ and $\mathrm{S}$, are given in Table 2 . The highest ratio values of $\mathrm{C} / \mathrm{H}$ and $\mathrm{S} / \mathrm{H}$ were found for vitamin $\mathrm{D}$-binding protein (8.29 and 8.25, respectively). This indicates that the relative abundance of vitamin D-binding protein in both groups $\mathrm{C}$ and $\mathrm{S}$ was more than 8 times higher than that of the normal $(\mathrm{H})$ group. The ratio values of $\mathrm{C} / \mathrm{H}$ and $\mathrm{S} / \mathrm{H}$ were 2.0 or higher for $42.9 \mathrm{kDa}$ haptoglobin (4.64 and 5.64, 


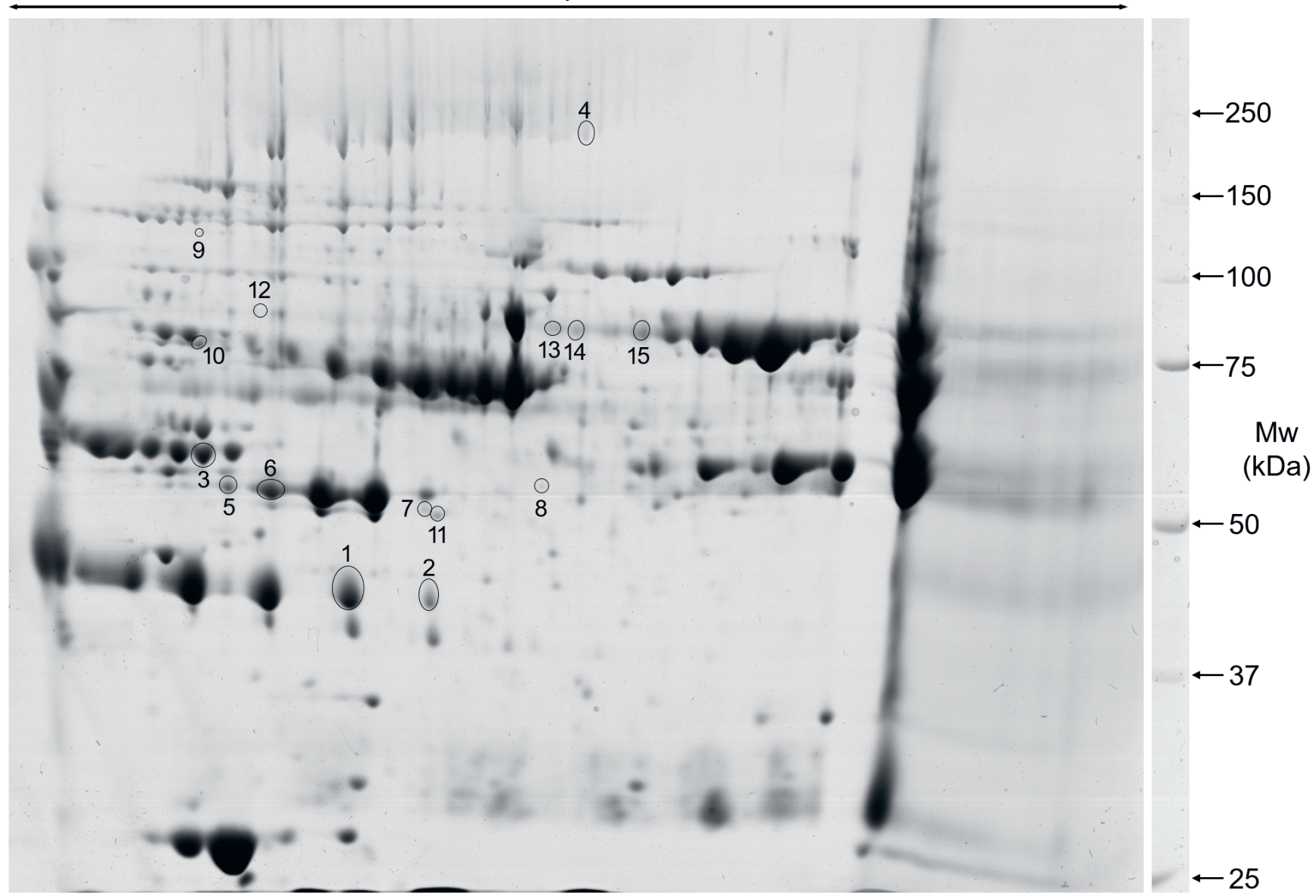

Fig. 1. Two-dimensional electrophoresis (2DE) map of the bladder cancer plasma proteins

Spots with significantly variable expression are identified. The differentially expressed protein spots are numbered and their characterization parameters are given in Table 1.

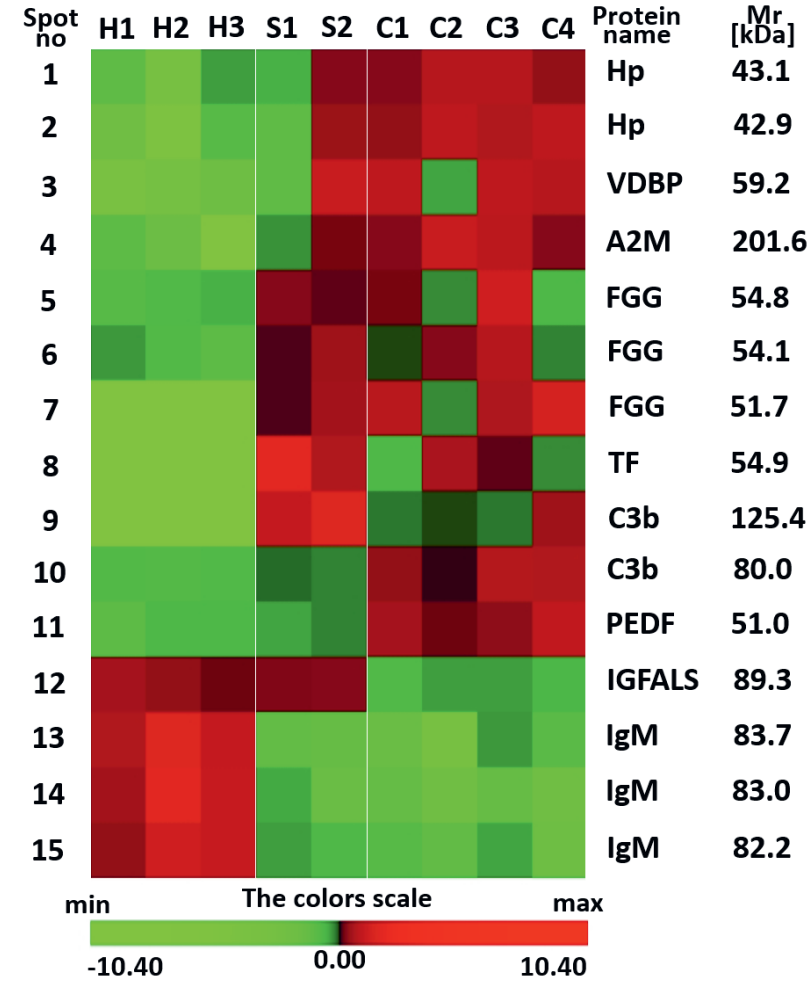

Fig. 2. A heat map describing the differences in protein expression patterns in the plasma of bladder cancer patients and healthy individuals

The comparative visualization was done for the differentially expressed proteins. The spot numbers correspond to those in Tables 1 and 2.

respectively), $43.1 \mathrm{kDa}$ haptoglobin (2.63 and 3.11, respectively), and alpha-2-macroglobulin (3.11 and 4.00, respectively). The ratio values of $\mathrm{C} / \mathrm{H}$ and $\mathrm{S} / \mathrm{H}$ for $54.8 \mathrm{kDa}$ and $54.1 \mathrm{kDa}$ fibrinogen forms (2.09 and 1.53, respectively, and 1.8 and 2.04 , respectively) and $80.0 \mathrm{kDa}$ complement $\mathrm{C} 3 \mathrm{~b}$ (2.25 and 1.6, respectively), and pigment epithelium-derived factor (2.23 and 1.67, respectively) ranged from 1.5 to 2.0. In contrast, low values of the ratio were found for IgM molecular forms $83.7 \mathrm{kDa}(0.25$ and 0.12 , respectively), $83.0 \mathrm{kDa}$ ( 0.20 and 0.13 , respectively) and $82.2 \mathrm{kDa}(0.33$ and 0.29 , respectively), when groups $\mathrm{C}$ and $\mathrm{S}$ were compared to group $\mathrm{H}$. Finally, the ratio value was nearly 1 for insulin-like growth factor binding protein when comparing $\mathrm{C}$ and $\mathrm{H}(0.64)$, and $\mathrm{S}$ and $\mathrm{H}(0.78)$ groups. On the other hand, similar ratio values were observed when comparing protein abundances in groups $\mathrm{C}$ and $\mathrm{S}$. 
Table 2. Relative abundance of the potential plasma biomarkers of bladder cancer identified by proteomic analyses

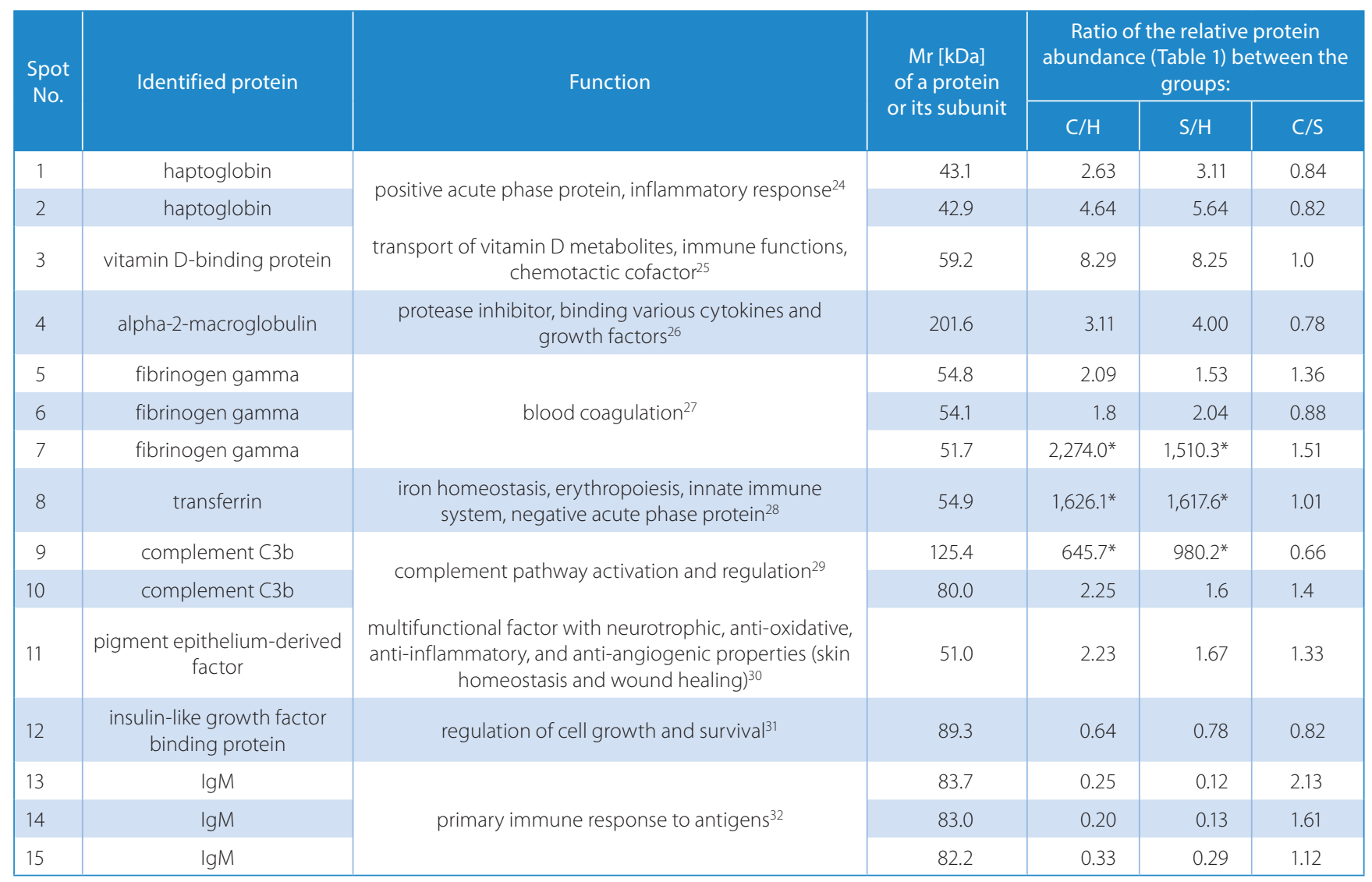

$\mathrm{C}$ - patients with bladder tumors; $\mathrm{H}$ - healthy controls; IgM - immunoglobulin $\mathrm{M} ; \mathrm{Mr}$ - molecular mass; $\mathrm{S}$ - patients suspected of having cancer; ${ }^{*}$ because the spot was not detected in the normal plasma sample, the given value corresponds to the value of the mean relative abundance (see Table 1).

\section{Discussion}

The proteomic analyses of plasma samples of the patients with urothelial bladder cancer and cystitis allowed us to visualize 15 differentially expressed protein spots, which were identified as 9 proteins (Fig. 1, 2 and Tables 1,2). The identified proteins showed some discrepancies between the calculated molecular masses (Mr) (Table 1) and the theoretical SwissProt/NCBI database matches. Such differences, also reported for some urine and plasma bladder cancer proteins, might be related to post-translational modifications (glycosylation and phosphorylation) and may have resulted from pathological tissue conditions (glycoxidation, proteolytic cleavage or association with other molecules), possibly influencing the size, properties and electrophoretic mobility of the affected molecule(s). ${ }^{18,22,33-35}$

Our results showed some changes between the 2 cancer groups in relation to the normal group, but none between group $C$ patients with active urothelial carcinoma and group $\mathrm{S}$ patients with acute cystitis. However, the patients from group $S$ had undergone a transurethral resection of a urothelial bladder tumor 2 years earlier, so they might have recurrent malignancy, still unidentified. On the other hand, the synthesis of the identified proteins is associated with the inflammatory state that is always present in cancer and of course in cystitis.
The protein identification of the 2DE pattern of spots (Fig. 1 and Table 1) revealed the presence of 2 molecular forms of haptoglobin ( $\beta$ chain: $43.1 \mathrm{kDa}$ and $42.9 \mathrm{kDa}$ ), 3 of IgM (heavy chain: $83.7 \mathrm{kDa}, 83.0 \mathrm{kDa}, 82.2 \mathrm{kDa}$ ), and moreover, 1 of a low molecular mass form of transferrin $(54.9 \mathrm{kDa})$, which were absent in the normal plasma. They probably represent several glycovariants of these glycoproteins. The relative abundance of haptoglobin, transferrin and IgM molecular forms in bladder cancer patients' plasma samples showed significant differences compared to those of the normal group (Table 2). Such differences might be associated with some defects in glycan structures of glycoproteins, which in malignancy may take a variety of forms, such as hypo- and hyper-glycosylated forms, leading to the occurrence of glycoforms with incomplete truncated oligosaccharide parts, heavily sialylated, fucosylated or branched structures, and even to the loss of expression or the appearance of novel structures. ${ }^{36}$ On the other hand, the presence of several spots of fibrinogen gamma $(54.8 \mathrm{kDa}$, $54.1 \mathrm{kDa}$ and $51.7 \mathrm{kDa}$ ) with evidently lower molecular masses than the untouched native form might reflect the presence of proteolytic degradation products rather than the occurrence of carbohydrate-deficient variants.

The proteomic analyses of bladder cancer plasma samples (Table 1) allowed us to distinguish 3 groups of plasma proteins, whose presence might be of value as 
potential bladder cancer markers. The $1^{\text {st }}$ one comprised the isoforms of proteins absent in the normal group, but occurring abundantly in the plasma of the cancer group (Table 1). They were $54.9 \mathrm{kDa}$ plasma transferrin, $51.7 \mathrm{kDa}$ fibrinogen gamma and $125.4 \mathrm{kDa}$ complement C3b. The $2^{\text {nd }}$ group consisted of glycoproteins released into circulation in high concentrations during immunoinflammatory processes. They are well-known members of the acute phase glycoprotein group, such as haptoglobin and alpha-2-macroglobulin, as well as 2 multifunctional glycoproteins, vitamin D-binding protein and pigment epithelium-derived factor $(51.0 \mathrm{kDa})$. The $3^{\mathrm{rd}}$ group of potential bladder cancer markers comprised 3 molecular forms of IgM (heavy chain of IgM: $83.7 \mathrm{kDa}$, $83.0 \mathrm{kDa}, 82.2 \mathrm{kDa}$ ), which may be involved in tumor immunity and biological changes in the tumors. ${ }^{37}$

Interestingly, our results show that vitamin D-binding protein is evidently associated with bladder cancer. Its relative abundance in patients' plasma samples was 8 times higher than in the normal plasma samples (Table 2). That multifunctional glycoprotein, besides its role in transporting vitamin D and circulating metabolites, is involved in the elimination of dead or injured cells, macrophage activation and neutrophil chemotaxis under inflammatory conditions. ${ }^{25,38}$ However, its involvement in the carcinogenesis of bladder cancer is controversial and requires further analysis. ${ }^{39}$

Among the selected differentially expressed glycoproteins, there are prognostic and predictive markers associated with several other cancers. An elevated concentration of transferrin has been described in the urine of bladder cancer patients. ${ }^{28}$ It not only takes part in normal iron metabolism, but is also involved in iron transport to highly proliferative cancer tissues, requiring high amounts of iron ions as a co-factor for ribonucleotide reductase enzyme for DNA synthesis. ${ }^{28}$ An elevated fibrinogen concentration in the plasma of bladder cancer patients has been described as an independent indicator of the late stage of the disease. ${ }^{27}$ The low abundance of IgM observed by us might reflect the disturbances in maintaining immunocompetence in specific recognition and elimination of precancerous, cancerous and age-related lesions in tissues. ${ }^{32}$ Simultaneously, in contrast to the decrease of the IgM level, the high abundance of complement $\mathrm{C} 3 \mathrm{~b}$ reflects the activation of innate immunity. To recapitulate, the parameters described by us are mostly related to bladder cancerlinked inflammatory responses, which are known to play decisive roles at different stages of tumor development. ${ }^{40}$

\section{Conclusions}

The results of proteomic analyses of the plasma samples of patients with urothelial bladder cancer allowed us to select 9 differentially expressed glycoproteins as potential bladder cancer markers. We recommend vitamin
D-binding protein, haptoglobin, transferrin, fibrinogen, IgM, complement C3b, alpha-2-macroglobulin, and pigment epithelium-derived factor as a group of markers associated with bladder cancer. They might be considered crucial parameters for the development of tests useful in clinical practice. However, in our opinion, the evaluation of haptoglobin, transferrin and $\operatorname{IgM}$ glycovariants, or various cleavage products of fibrinogen and complement $\mathrm{C} 3 \mathrm{~b}$ might be more promising and more sensitive and specific than the evaluation of their total respective protein concentrations for bladder cancer diagnosis and disease progression monitoring.

Considering the complexity of the proteomic technique we used and the future usefulness of the test in clinical practice, the results should be confirmed by less expensive and time-consuming methods in a larger group of patients.

\section{References}

1. Kaufman D, Shipley WU, Feldman AS. Bladder cancer. Lancet. 2009; 374(9685):239-249.

2. Yang N, Feng S, Shedden K, et al. Urinary glycoprotein biomarker discovery for bladder cancer detection using LC/MS-MS and labelfree quantification. Clin Cancer Res. 2011;17(10):3349-3359.

3. Goodison S, Rosser ChJ, Urquidi V. Bladder cancer detection and monitoring: Assessment of urine- and blood-based marker tests. Mol Diagn Ther. 2013;17(2):71-84.

4. Gutiérrez Baños JL, del Henar Rebollo Rodrigo M, Antolín Juárez FM, García BM. Usefulness of the BTA STAT test for the diagnosis of bladder cancer. Urology. 2001;57(4):685-689.

5. Chang YH, Wu CH, Lee YL, Huang PH, Kao YL, Shiau MY. Evaluation of nuclear matrix protein-22 as a clinical diagnostic marker for bladder cancer. Urology. 2004;64(4):687-692.

6. Kageyama $\mathrm{S}$, Isono $\mathrm{T}$, Iwaki $\mathrm{H}$, et al. Identification by proteomic analysis of calreticulin as a marker for bladder cancer and evaluation of the diagnostic accuracy of its detection in urine. Clin Chem. 2004;50(5):857-866.

7. Santoni M, Catanzariti F, Minardi D, et al. Pathogenic and diagnostic potential of BLCA-1 and BLCA-4 nuclear proteins in urothelial cell carcinoma of human bladder. Adv Urol. 2012;2012. doi: $10.1155 / 2012 / 397412$

8. Willson CJ, Flake GP, Sills RC, Kissling GE, Cesta MF. Immunohistochemical expression of cyclin D1, cytokeratin 20, and uroplakin III in proliferative urinary bladder lesions induced by o-nitroanisole in Fischer 344/N rats. Vet Pathol. 2016;53(3):682-690.

9. Menéndez V, Fernández-Suárez A, Galán JA, Pérez M, García-López F. Diagnosis of bladder cancer by analysis of urinary fibronectin. Urology. 2005;65(2):284-289.

10. Tiveron RC, de Freitas LC, Figueiredo DL, Serafini LN, Mamede RC, Zago MA. Expression of calcium binding protein S100 A7 (psoriasin) in laryngeal carcinoma. Braz J Otorhinolaryngol. 2012;78(4):59-65.

11. Irmak S, Tilki D, Heukeshoven J, et al. Stage-dependent increase of orosomucoid and zinc-alpha2-glycoprotein in urinary bladder cancer. Proteomics. 2005;25(16):4296-4304.

12. Vasala K, Kuvaja P, Turpeenniemi-Hujanen T. Low circulating levels of ProMMP-2 are associated with adverse prognosis in bladder cancer. Tumour Biol. 2008;29(5):279-286.

13. Szarvas T, László V, Vom DorpF, et al. Serum endostatin levels correlate with enhanced extracellular matrix degradation and poor patients' prognosis in bladder cancer. Int J Cancer. 2012;130(12):2922-2929.

14. Matsumoto K, Shariat SF, Casella R, Wheeler TM, Slawin KM, Lerner SP. Preoperative plasma soluble E-cadherin predicts metastases to lymph nodes and prognosis in patients undergoing radical cystectomy. J Urol. 2003;170(6 Pt 1):2248-2252.

15. Washino S, Hirai M, Matsuzaki A, Kobayashi Y. Clinical usefulness of CEA, CA19-9, and CYFRA 21-1 as tumor markers for urothelial bladder carcinoma. Urol Int. 2011;87(4):420-428. 
16. Orenes-Piñero E, Cortón M, González-Peramato P, et al. Searching urinary tumor markers for bladder cancer using a two-dimensional differential gel electrophoresis (2D-DIGE) approach. J Proteome Res. 2007;6(11):4440-4448.

17. Røtterud R, Malmström PU, Wahlqvist R, Taskén KA. The star chart to Ta bladder cancer: An unsophisticated analysis of two-dimensional gel electrophoresis proteome maps. Scand J Urol Nephrol. 2010;44(2): 76-83.

18. Lee YR, Chen YW, Tsai MC, Chou HC, Chan HL. Redox- and expression-proteomic analysis of plasma biomarkers in bladder transitional cell carcinoma. Mol Biosyst. 2012;8(12):3314-3324.

19. Sobin LH, Gospodarowicz MK, Wittekin Ch, eds. TNM Classification of Malignant Tumours. $7^{\text {th }}$ ed. Hoboken, NJ: Union for International Cancer Control (UICC) \& Wiley-Blackwell; 2009.

20. Bladder urothelial nonneoplastic lesions WHO/ISUP classification 2004. http://www.pathologyoutlines.com/topic/bladderwhoisup. html. Accessed February 13,2017.

21. Lepczyński A, Herosimczyk A, Ożgo M, et al. Dietary supplementation with dried chicory root triggers changes in the blood serum proteins engaged in the clotting process and the innate immune response in growing pigs. J Physiol Pharmacol. 2015;66(1):47-55.

22. Ożgo M, Lepczyński A, Herosimczyk A. Two-dimensional gel-based serum protein profile of growing piglets. Turk J Biol. 2015;39(2): 320-327.

23. Caraux G, Pinloche S. PermutMatrix: A graphical environment to arrange gene expression profiles in optimal linear order. Bioinformatics. 2005;21(7):1280-1281.

24. Yoon SJ, Park SY, Pang PC, et al. N-glycosylation status of beta-haptoglobin in sera of patients with prostate cancer vs benign prostate diseases. Int J Oncol. 2010;36(1):193-203.

25. Chun RF. New perspectives on the vitamin D binding protein. Cell Biochem Funct. 2012;30(6):445-456.

26. Feige JJ, Negoescu A, Keramidas M, Souchelnitskiy S, Chambaz EM. Alpha 2-macroglobulin: A binding protein for transforming growth factor-beta and various cytokines. Horm Res. 1996;45(3-5):227-232.

27. Liu J, Li D, Cao L, et al. Elevated preoperative plasma fibrinogen level is an independent predictor of malignancy and advanced stage disease in patients with bladder urothelial tumors. Int J Surg. 2016;36 (Pt A):249-254.
28. Halder S, Dey RK, Chowdhury AR, Bhattacharyya P, Chakrabarti A. Differential regulation of urine proteins in urothelial neoplasm. J Proteomics. 2015;127(Pt A):185-192.

29. Ramadass M, Ghebrehiwet B, Kew RR. Enhanced recognition of plasma proteins in a non-native state by complement C3b. A possible clearance mechanism for damaged proteins in blood. Mol Immunol. 2015;64(1):55-62.

30. Chen L, DiPietro LA. Production and function of pigment epitheliumderived factor in isolated skin keratinocytes. Exp Dermatol. 2014;23(6): 436-438.

31. Baxter RC. IGF binding proteins in cancer: Mechanistic and clinical insights. Nat Rev Cancer. 2014;14(5):329-341.

32. Ujvari B, Hamede R, Peck S, et al. Immunoglobulin dynamics and cancer prevalence in Tasmanian devils (Sarcophilus harrisii). Sci Rep. 2016;6:25093.

33. Li H, Li C, Wu H, et al. Identification of Apo-A1 as a biomarker for early diagnosis of bladder transitional cell carcinoma. Proteome Sci. 2011;9:21.

34. Frantzi M, Latosinska A, Flühe L, et al. Developing proteomic biomarkers for bladder cancer: Towards clinical application. Nat Rev Urol. 2015;12(6):317-330.

35. Lepczyński A, Herosimczyk A, Ożgo M, et al. Dietary chicory root and chicory inulin trigger changes in energetic metabolism, stress prevention and cytoskeletal proteins in the liver of growing pigs: A proteomic study. J Anim Physiol Anim Nutr (Berl). 2016;66(1):47-55.

36. Varki A, Kannagi R, Toole BP. Glycosylation changes in cancer.In:Varki A, Cummings RD, Esko JD, et al., eds. Essentials of Glycobiology. $2^{\text {nd }}$ ed. Cold Spring Harbor, NY: Cold Spring Harbor Laboratory Press; 2009.

37. Zhang L, Zhao F, Liang Z, et al. Effect of anti-human IgM antibody on the proliferation, apoptosis and cell cycle of Hep-2 laryngeal squamous cell carcinoma cells and potential mechanisms underlying its antitumor activity. Int J Clin Exp Pathol. 2017;10(2):858-868.

38. Speeckaert MM, Speeckaert R, van Geel N, Delanghe JR. Vitamin D binding protein: A multifunctional protein of clinical importance. Adv Clin Chem. 2014;63:1-57.

39. Mondul AM, Weinstein SJ, Virtamo J, Albanes D. Influence of vitamin $D$ binding protein on the association between circulating vitamin D and risk of bladder cancer. Br J Cancer. 2012;107(9):1589-1594.

40. Grivennikov SI, Greten FR, Karin M. Immunity, inflammation, and cancer. Cell. 2010;140(6):883-899. 